\title{
On the Question of the Place and Role of Language in the Process of Personality Socialization: Structural-Ontological Sketch
}

\section{К вопросу о месте и роли языка \\ в процессе социализации личности: структурно-онтологический эскиз}

Vitalii Shymko

Dr. in Psychology,

Professor
Виталий Шимко

доктор психологических наук, профессор

E-mail: shymko@,outlook.com orcid.org/0000-0003-4937-6976

\author{
Pereiaslav-Khmelnytskyi \\ Hryhorii Skovoroda \\ State Pedagogical University \\ $\triangle$ 30, Sukhomlynskyi Str., \\ Pereiaslav-Khmelnytskyi, Kyiv Reg., \\ Ukraine, 08401
}

\begin{abstract}
ГВУЗ «Переяслав-
Хмельниикий государственный педагогический университет имени Григория Сковороды» $\triangle$ ул. Сухомлинского, 30, г. Переяслав-Хмельницкий,
\end{abstract} Киевская обл., Украина, 08401

Original manuscript received May 04, 2019

Revised manuscript accepted September 10, 2019

\begin{abstract}
Objective - is to formulate a methodological discourse regarding the place and role of the language interconnected with the process of socialization of a person and develop a systemic idea of the corresponding functional features.

Materials \& Methods - this discourse is formulated on the basis of a systemic idea of the personality socialization, which, in turn, is realized using the structural-ontological method of studying the subject matter field in interdisciplinary researches. This method involves the construction of special visual-graphic matrices that reflect the interaction of the primary process and the material of the studied system.
\end{abstract}


Results. The work with the structural-ontological matrix made it possible to analyze the functions of the language in the context of such significant factors of socialization as complex psychodynamics, civilization space and the function of reflection. At the same time, reflection is considered at the level of two plans - primary (reflectionbond) and secondary (reflection-splitting). This made it possible to deduce the idea of the role of language beyond the traditional framework of working with text and analyze the place of the language in the context of activities to establish a connection between individuals, which is realized in a specific cooperative situation (Shchedrovitsky). In particular, the look at language as a specific tool of civilizational rationing, the mechanism of which is provided through reflection-communication. Thus, the language is examined through the prism of its systemic influence on the morphology of the psyche.

Conclusions - a structural-ontological analysis of the place and role of language in the process of personality socialization has led us to construction of a hypothesis about the phenomenon of language discontentment, as a tendency to distance away egoconsciousness in the process of individuation from linguistic ontology. The arguments were also advanced in favor of the assumption regarding the peculiarities of the influence of language discontentment on cultural activities and the psychodynamic contribution of this phenomenon in the midlife crisis (Jung).

Key words: language, personality socialization, individuation, structural ontology, systemic methodology.

\section{Introduction}

The place and role of language in the process of personality socialization remains an urgent scientific problem that has been solved for many decades. Corresponding attempts are carried out in the framework of numerous pedagogical, linguistic, psychological, neurocognitive, anthropological, cultural, ethnographic, historical and other studies. The obvious interdisciplinary nature of this issue leads to the use of a systemic approach to the study of problems, increasingly implemented in recent years (Ananina, 2006; Bazylova et al., 2015; Chafe, 1994; Chenki, 1996; Dosimova, 2008; Garrett, 2008; Garrett \& Baquedano-López, 2002; Girutsky, 2007; Hachmafova \& Makerova, 2010; Karasik, 2004; Kulick \& Bambi, 2004; Krasnykh, 2000; Ochs \& Bambi, 2012; Vorobev, 2008; Zamilova, 2013 et al.). At the same time, in most cases, researchers solve narrowly defined theoretical or applied scientific problems. There are no new conceptual views on the connection of language with the process of personality socialization. 
This is partly due to methodological difficulties that inevitably arise in an interdisciplinary study of subject matter fields with a multifactorial causal structure of the phenomena studied. The purpose of this article is to present the results of a systemic understanding of the place and role of language in the process of personality socialization. The corresponding methodological discourse is formed using the author's method of structural-ontological analysis of the subject matter area of interdisciplinary researches.

\section{Methods and Techniques of the Research}

The structural-ontological method was developed in the framework of the tradition of the systematic methodology of Shchedrovitsky (1966, 1982, 1995). It involves a special procedure for constructing visualizations - structural-ontological matrices that reflect the main components of the system description of the studied object. Subsequent analysis of the object allows you to extract the research subject matter from it and, thereby, specify the answer to the methodological question «WHAT exactly is being investigated?». Among other things, the method allows to schematize the logic of how the material of the system is transformed by its primary process. In turn, this allows to describe the morphology of the system. Matrices provide visibility of structural and functional features and interactions of system components, as well as its relationship with supersystems. These and other, including procedural, features of the application of the method are disclosed in a number of our previous publications and are available both for acquaintance and for scientific and methodological discussion (Shymko, 2016, 2018a, 2018b, 2018c, 2019a).

Obviously, in the case under consideration, the process of personality socialization acts as a system object, the structuralontological disclosure of which is a prerequisite for developing a view of the appropriate place and role of the language. The construction of the structural-ontological matrix involves a graphical representation using perpendicular axes of such characteristics of the system as the material and the primary process. In addition, each axis should dichotomously display the properties of the corresponding parameters. The procedural and technical nuances of constructing this matrix, as well as working 
with it, are described in detail in a separate thematic series of online publications (Shymko, 2019b), which allows us in this article to focus on a review of the significant milestones of the analysis.

As the material of the system, the psyche was defined as an energy phenomenon. To clarify the corresponding dichotomous concept, we used Jung's structural ideas about the psyche and its differentiation in the process of personality socialization $(1923,1969 a, 1969 b)$. The starting point of the psyche according to Jung is represented by the collective unconscious (archetypes). The final position is an individuated consciousness that is formed as a result of the personality socialization, which Jung calls the process of individuation.

Considering the psyche in terms of energy, the discharge of tension is defined as the primary process of the system. The corresponding dichotomy on one pole of the axis is represented by the maximum possible intrapersonal stress, on the opposite - its principal absence. The specified tension is associated with the emergence of critical situations in the process of personality socialization. The corresponding part of the dichotomy we have designated is the impossibility of being. We owe the wording to the work of the outstanding scientist Vasilyuk concerning the connection between the phenomenon of experience and «situations of impossibility» (Vasilyuk, 1991). The second part of the dichotomy representing the process is completely free of any tension per se. In essence, this is death, as a transcendental non-existential category, excluding any possibility of tension. We designated this part of the dichotomy as inexistence.

The above identification of dichotomies made it possible to form a matrix (Fig. 1), which axes covers the ontological boundaries of the studied object and defines the structure of the corresponding «knowledge construct» (Shchedrovitsky, 1982). The procedure for identifying the structural components (segments) of a matrix is explained in detail and described by us in a separate publication (Shymko, 2019c). The study of the composition of segments and intersegment interactions allowed us to form ideas about the socialization of the personality, which involves changes in the material of the system associated with the Jungian concept of individuation - the natural process of differentiation of the psyche.

«Individuation is the process of formation and isolation of single creatures; Speaking specifically, it is the development of a 
psychological individual as a creature that is different from general, collective psychology $<\ldots>$ Individuation is naturally necessary, since delaying individuation through primary or exclusive normalization on a collective scale means damage to individual life. But individuality has already been given physically and physiologically, and accordingly it is expressed psychologically» (Jung, 1969b).

How exactly does «the formation and isolation of individual beings» occur? The quality milestone of individuation is the emergence of the ego - the central element of consciousness. Jung prefers to use the term ego-consciousness, which means a complex (a structural unit of the psyche in analytical psychology), ontologically represented by a set of ego-relationships. According to Jung, complexes are vertically integrated building blocks of the psyche. Their formation occurs within the framework of the psychodynamic segment of the matrix, but is not limited to it and covers the entire psyche. The non-individuated (infantile) ego is subject to unconditional constellating influence from the complexes. A qualitative characteristic of individuated consciousness is the ability to distinguish and to a certain extent exert influence on complexes. The first half of life is associated with the formation and strengthening of "productive» complexes (in fact, personality traits) that allow a person to perform a biological task. The second half of life, on the contrary, is associated with the «liberation» of the ego from the influence of complexes. In both cases, situations of impossibility of being are actualized, which, according to Jung, determine the occurrence of reflection.

«One might even consider that the rather early emergence of the human ability to reflect came from the painful consequences of severe emotional upheaval» (Jung, 1969a). At the same time, Jung directly connects reflection with the function of thinking, which provides the possibility of the formation of experience. «I believe that the principles of scientific empiricism remain unbreakable if we occasionally turn to thoughts that go beyond the simple collection and classification of experimental data. Moreover, I believe that without reflection there is no experience, since «experience» is an assimilation process, without which it is impossible to understand what is happening » (Jung, 1969a).

Thus, our reasoning actualized the view of reflection in the context of the category - activity. «Reflection exists in the activity, is a special structure and a special mechanism in the activity ... Reflection 
is the moment, side, mechanism and organization of the activity» (Shchedrovitsky, 1995). At the same time, Shchedrovitsky draws attention to the presence of different plans of reflection, at least two forms of its existence: «If we want to understand the fundamental moments of reflection, its « initial »nature, so to speak, we must first of all postulate that this is not a work of consciousness, not a mechanism for splitting consciousness into self-consciousness in the classical sense - all this will be explained as a manifestation of more high forms of existence of reflection; it is a special bond of cooperation, or, in other words, a connection of several initially independent acts of activity. The second point that I highlight $\langle\ldots\rangle$ is the assertion that reflection is an act of activity about the connection or structure of communication between two, at least individuals. We are talking about such communication in which one individual said something to another about some real or conceivable situation, and the second individual understands this text» (Shchedrovitsky, 1995).

In connection with the foregoing, in our study we distinguished two types of reflection - primary (reflection-bond) and secondary (reflection-splitting). We draw attention to the fact that reflection-bond involves deciphering the text, but is not limited to this and is not reduced to understanding the text. The key aspect here is the activity of establishing a connection between individuals, which is realized in a specific cooperative (co-activity) situation:

«The core and essence of reflection is such an organization of the situation, which is uniform for all acting individuals, which enables all individuals, despite the differences in their positions and the objective difference in the meanings that must be formed, see, understand and restore the same thing in these situations. objectified, and therefore rationed meaning » (Shchedrovitsky, 1995).

Thus, reflection-bond differs from understanding in that, in addition to linguistic means, situational-activity factors take part in the reconstruction of the subject matter of thought from the text. The principal mechanism of reflection is the situation of cooperation. Therefore, the ontological space in which these situations unfold (the first segment of the matrix) is not a «language field» (Lacan, 2006), but a wider dimension. A dimension that, in addition to language, consists of diverse situations generated by intersecting activities - civilization space 
or simply civilization. In this dimension, language is an instrument, and reflection-bond is a mechanism of appropriate rationing.

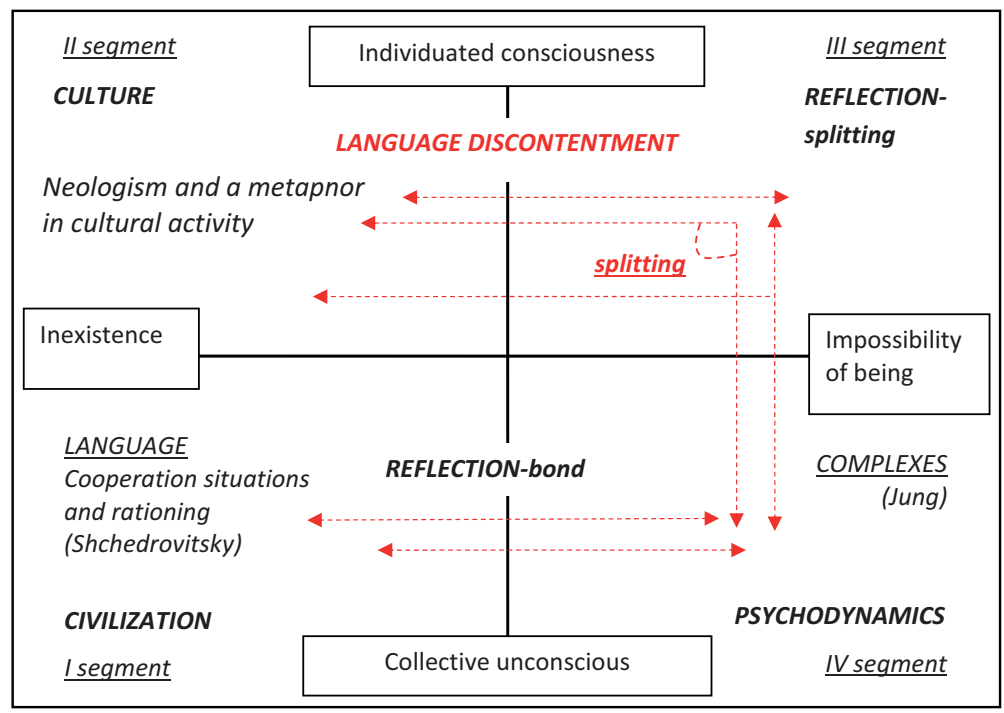

Fig. 1. Structural-ontological matrix of personality socialization as an object of systemic research

Figuratively speaking, situations of cooperation fulfill the function of «crutches» of socialization, without which any personal progress and adaptation would not be thought possible. On the one hand, active participation in cooperation performs the function of discharging stress associated with the primary process of the analyzed system (horizontal axis of the matrix). Tension «pushes» a person outside, in the field of civilizational interaction. On the other hand, involvement in cooperation actualizes the problem of rationing, which in itself is a situation of impossibility. Discharging of one stress generates another. Thus, reflection-bond arises as a binding tension. We assume that the energy of this tension is encapsulated in complexes - repositories of ideological and affective content replenished in the process of socialization. For these reasons, in the scheme (Fig. 1), the reflection-bond is displayed in the form of line-snippets with end-directed opposite arrows connecting the fourth and first segments of the matrix. The ego's access to the described «data bank» can be twofold. Through a reflective channel, such access is, in fact, an experience. The non-reflexive access of the ego to the contents of the complex is memory. 
The work of the «pendulum» of reflection is involved in the differentiation of the material of the system, which is also accompanied by the development of ego-consciousness functions, the accumulation of memories and the formation of experience. The latter, from our point of view, is gradually preparing an internal «replacement» in relation to situations of cooperation that were initially localized externally. As a result of the development of the reflection-bond function itself and the internalization of its products, the formation of an alternative ontological space is ensured. With the acquisition of socialization experience, a split occurs (Fig. 1) between the «horizontal» scenario of primary reflection and its «vertical» secondary neoplasm. In fact, this forms a structural conflict, in our opinion, generating a midlife crisis and causing some specific functions of the language, which will be discussed later.

\section{Results and Discussions}

According to our matrix, the ontological place of the language corresponds to the first segment (Fig. 1). Thus, civilization provides the ability to unify (reflection-bond) through language. The psyche is not just meaningfully «absorbed» from the outside. Civilization also performs a structure-forming (generating) function in relation to psychodynamics (the fourth segment of the matrix). In this regard, let us recall Lacan's ideas about the structural connection of the unconscious and language, the biolinguistic position of Chomsky and other concepts. Of enormous importance for our analysis is the fact that the intersegment connection under consideration gives the material of the system organization with the help of language, as a specific tool of civilization rationing. In the process of individuation, thanks to the work of reflection-splitting, the ego begins to «fall out» of a productive interaction with civilization, alienate itself from external situations of cooperation, devalue and make senseless of them.

The foregoing makes us ask a clarifying question - what exactly is the ego alienated from? What exactly is that substance in relation to which the ego takes a centrifugal position? Actualization of this issue brings our locus to the connection between the next pair - reflection and psychodynamics (third and fourth segments, Fig. 5). And the answer to this question itself is obvious, if we recall that situations of 
cooperation (Shchedrovitsky) realize themselves only through language. So, in addition to the already mentioned features of communication on the line of psychodynamics - reflection in the analysis of two types of reflection, we formulate the following hypothesis. Development of reflection-splitting determined by the individuation alienates the ego from civilizational ontology, which is objectified through the tendency to abandon language as the manifestation of dissatisfaction with it (hereinafter - language discontentment) or, at least, through distance from the corresponding being.

We assume that dissatisfaction with the language manifests itself in a wide behavioral spectrum - from silence (literal refusal) to the preference for non-linguistic forms of communicative activity (music, dance, pantomime, etc.). However, the connection with the language is not just strong, it is structural and in this sense fundamental to the person. Therefore, de-linguization is simply impossible without the destruction of personality. As a result, language discontentment realizes itself partially, marginally and in two directions, which are obvious when considering the structural-ontological matrix that we have proposed. First, on the line of realization of «discontentment» (third and fourth segments, Fig. 1) are psychodynamic structures formed by the language and / or with the participation of the language - complexes as «affectively charged ideas» (Jung, 1969a). We assume that it is this «bias» that causes the destabilization of the worldview during the midlife crisis, the re-actualization of infantile memories, perceptual scenarios, behavioral patterns, etc. Secondly, language discontentment brings (the second and third segments, Fig. 5) to the cultural (redemptive, according to Jung) activity, the spirit of neologism and metaphor (see below).

The particular drama of the conflict we described between the two types of reflections is that the language is between a rock and a hard place of two psychodynamic factors, the morphology of which is due to it (language). Figuratively speaking, there is a struggle against language and with the help of language. The situation is further complicated by the impossibility of de-linguization of a person without psychological annihilation. The reduction of the structure of the psyche to a level where only one of the reflections would functioning is equivalent to the occurrence of severe morbid states. And finally, the development and withdrawal of the mental organization of the personality to a qualitatively new level, where conflicting factors would be qualitatively 
«reconciled,» in our opinion, lies in the plane of metaphysical speculation. As you can see, the nature of the conflict in question is fundamentally counterproductive.

In other words, the emerging situation of the impossibility of being creates tension without a creative (structure-forming) vector, which leaves the only direction of stress relief available - response (to cultural activity). It is important to consider that along with language discontentment, this discharge contains «redeeming motivation» (Jung, 1969b). The conflict of reflections executes in a complex, contradictory scenario. Namely, in a single motivational momentum for cultural activity there is an aggression of frustration origin, the negative value of language and a sense of guilt before civilization.

Returning to the thesis about opposing language with the help of language, we ask ourselves a question - how is this possible in practical terms? In our opinion, the simplest and most common option is through the mechanism of neologization. Here, the term implies not so much the introduction of fundamentally new grammatical units into the language, which is the «tip of the iceberg» of neologization, understood in a linguistic way. We understand this term in the context of psychological defense, the dynamic meaning of which is to relieve stress from the impossibility of being and to realize the motivation with the motivational orientation described above. Such protection realizes itself through a variety of psycholinguistic mechanisms of multiplication of language units and manifests itself in the whole spectrum of grammatical phenomena - synonymy, antonymy, homonymy, polysemy, etc.

In our opinion, these mechanisms are not specific to the language discontentment. They probably arise in the process of the evolutionary development of the language and fulfill the function of expanding the linguistic forms necessary for an adequate description of the multifaceted reality (both external and internal). However, these mechanisms are used as channels for relieving stress caused by language discontentment. This leads to the obvious «redundancy» of language tools, from the point of view of human adaptation, not only in a narrow biological, but also in a broad social (in terms of our thinking - civilizational) senses.

So, individuated persons often, firstly, can not only express their experiences with linguistic means, but also «fit» themselves into the language in a cognitive sense, while comprehending issues on a wide thematic spectrum: from daily domestic to professional and creative. 
This causes the indicated category of people to strive to increase the level of the so-called verbal culture of their native languages and often motivates them to study foreign languages. According to our assumption, in individuals adaptively experiencing a midlife crisis, language discontentment manifests itself in a conditionally mild form, which seems acceptable to us to call it - dissatisfaction with the insufficiency of language. Secondly, individuation is accompanied by a literal neologization of the language, implemented by the introduction of new words and concepts in the framework of cultural activities. Of course, such introductions are reflected in both the formal and substantive characteristics of these activities. Disclosure of the relevant details requires a detailed separate statement, which we do not stop here for.

Similarly, language discontentment «penetrates» culture through metaphorization, which we also understand in line of psychological defense, while remaining in the orbit of the classical Aristotelian view of «art as an imitation of life.» If neologization assumes the work of defense at the level of the word-concept, then metaphorization refers to the level - plot-discourse. Actually, our reasoning is in favor of the assumption that in the process of individuation, a person predominantly imitates the imitation of life. This issue is not much debatable if one recalls the "wall of the language» of Lacan, on the other side of which is the Real, not symbolized by language, and available only in dreams and in psychosis (Lacan, 2006).

The imitation of imitation is clearly visible in the repeatability of plots and discourses in any products of speech activity - from spontaneous speech utterances to literary classics. Lacan explained this as a manifestation of the natural limitations of the language, claiming that there are only four discourses, three of which are a subspecies of one (Lacan, 2006). We find in Jung a more optimistic formulated view of the theoretical existence of as many archetypes (and hence plots) as there are life situations. However, all archetypes also originate at one point (Self), from the singularity of which binary Eros and Logos appear, and all other archetypes can be reduced to the indicated trinity (Jung, 1969a). Propp's «Morphology of the Folktale» (1968) leaves no room for serious doubt in this matter and allows us to keep politeness, avoiding the further listing of a number of remarkable scientists whose conclusions are similar. 


\section{Conclusions}

Summarizing the results of the theoretical analysis, we note that this paper sets out a methodological discourse regarding the place and role of language associated with the process of personality socialization. The indicated discourse is formulated on the basis of a systemic concept of the socialization, which, in turn, is realized using the structural-ontological method of studying the subject matter field in interdisciplinary researches. This made it possible to analyze the functions of the language in the context of such significant factors of socialization as complex psychodynamics, civilization space and the function of reflection. In this case, the reflection is considered at the level of the two plans - primary (reflection-bond) and secondary (reflectionsplitting). It allowed to deduce the idea of the role of language beyond the traditional framework of working with text and analyze the place of the language in the context of the activity of establishing a connection between individuals, which is realized in a specific cooperative situation (Shchedrovitsky). In particular, to look at language as a specific tool of civilizational rationing, the mechanism of which is provided through reflection-bond. Thus, language is considered through the prism of its systemic impact on the morphology of the psyche. In turn, this allowed us to come to the construction of a hypothesis about the phenomenon of language discontentment, as a tendency to distance ego-consciousness in the process of socialization from linguistic ontology. Assumptions were also formulated regarding the characteristics of the influence of language discontentment on cultural activities and the psychodynamic contribution of this phenomenon in a midlife crisis (Jung).

Among the prospects for further research in this area, of particular interest, in our opinion, is the empirical verification of the differentialpsychological, cultural, civilizational, age and pedagogical features of the influence of language on the process of personality socialization.

\section{References}

Ananina, T.V. (2006). Jemocii i jazykovaja kartina mira [Emotions and Language Picture of the World]. Vestnik Kazahstansko-Amerikanskogo svobodnogo universiteta - Bulletin of the Kazakhstan-American Free University, 2, 92-99 [in Russian]. 
Bazylova, B., Kazhigalieva, G., Kazhigaliyeva, G., Tazhibayeva, S., Zhussupova, Z. and Ergalieva, Z. (2015) Language as an Instrument of Socialization and a Representation of National Linguistic Personality. Creative Education, 6, 71-78. https://doi.org/10.4236/ce.2015.61006

Chafe, W. (1994). Discourse, Consciousness and Time. The Flow and Displacement of Conscious Experience in Speaking and Writing. Chicago: Univ. Chicago of Press.

Chenki, A. (1996). Modern Cognitive Approaches to Semantics of Similarities and Differeces in Theories and Goals. Problems of Linguistics, 2, 68-78.

Dosimova, M.S. (2008). Nacionalnaja specifika jazykovoj obektivacii koncepta «zhenshhina»: na materiale russkogo i kazahskogo jazykov [National Specifics of Language Objectivization of a Concept «Woman»: On the Material of the Russian and Kazakh Languages]. Candidate's thesis. Astrahan. Astrahanskij universitet [in Russian].

Garrett, P.B., \& Baquedano-López, Patricia (2002). Language socialization: Reproduction and continuity, transformation and change. Annual Review of Anthropology, 31, 339-361. https://doi.org/10.1146/annurev.anthro.31.040402.085352

Garrett, P.B. (2008). Researching Language Socialization. In Kendall A. King \& Nancy H. Hornberger (Eds.), Encyclopedia of Language and Education (Vol. 10, pp. 189-201). Springer, Boston, MA. https://doi.org/10.1007/978-0-387-30424-3

Girutsky, A.A. (2007). Belorussko-russkij hudozhestvennyj bilingvism: tipologija $i$ istorija, jazykovye processy [Beloruss-Russian Art Bilingualism: Typology and History, Language Processes]. Minsk: Vysshaja shkola [in Russian].

Hachmafova, Z.R., \& Makerova, S.R. (2010). Kognitivnye sistemy jazykovoj lichnosti $\mathrm{v}$ processe interpretacii hudozhestvennogo teksta [Cognitive Systems of Linguistic Identity in the Process of Interpretation of a Literary Text]. Vestnik MGOU Bulletin MSRU, 1, 51-56 [in Russian].

Jung, C.G. (1923). Psychological types; or, The Psychology of Individuation. London: Paul, Trench, Trubner.

Jung, C.G. (1969a). Archetypes and the Collective Unconscious [sic]. Collected Works of C.G. Jung. (Vol. 9, Part 1). Princeton, N.J.: Princeton University Press.

Jung, C.G. (1969b). Aion: Researches into the Phenomenology of the Self. Collected Works of C.G. Jung (Vol. 9, Part 2). Princeton, N.J.: Princeton University Press.

Karasik, V.I. (2004). Jazykovoj krug: lichnost, koncepty, diskurs [Language Circle: Person, Concepts, Discourse]. Moscow: Gnozis [in Russian].

Kulick, Don, \& Bambi B., Schieffelin. (2004). Language socialization. In Alessandro Duranti (Ed.), A Companion to Linguistic Anthropology (pp. 349-368). Malden, MA: Blackwell.

Krasnykh, V.V. (2000). Jazyk, Soznanie, Kommunikacija [Language, Consciousness, Communication]. In V.V. Krasnykh \& A.I. Izotov (Eds.), Sbornik statej Collection of Articles. (Vol. 10, pp. 41-51). Moscow: Dialogue Moscow State University [in Russian].

Lacan, J. ([1953] 2006). The Function and Field of Speech and Language in Psychoanalysis. In J. Lacan (Ed.). Écrits: The First Complete Edition in English (translated with notes by B. Fink in collaboration with H. Fink and R. Grigg), (pp. 237-68). New York: Norton.

Ochs, E., \& Bambi, B.S. (2012). The Theory of Language Socialization. In Alessandro Duranti, Elinor Ochs \& Bambi Schieffelin (Eds.), The Handbook of Language Socialization (pp. 1-21). Malden, MA: Wiley-Blackwell. https://doi. org/10.1002/9781444342901.ch1 
До питання про місиее $і$ роль мови в процесі сойіалізації...

Propp, V (1968). Morphology of the Folktale (2 $2^{\text {nd }}$ ed.). University of Texas Press.

Shchedrovitzky, G.P. (1966). Methodological problems of system research. General Systems, XI (Translated by A. Rapoport). URL: https://www.fondgp.ru/old/gp/ biblio/eng/5.html

Shchedrovitsky, G.P. (1982) Methodological organization of systems-structural research and development: principles and general framework. General Systems, XXVII (Translated by A. Rapoport). URL: https://www.fondgp.ru/old/gp/biblio/eng/4.html

Shchedrovitsky, G.P. (1995). Izbrannye trudy [Selected Works]. Moscow: Shkola Kulturnoj Politiki [in Russian].

Shymko, V.A. (2016). Sistemna lokalizacija predmeta v psihologichnih doslidzhennjah: procedura strukturno-ontologichnoï vizualizaciï [Systemic Localisation of the Object in Psychological Research: Structural and Ontological Visualization]. Visnik Kiivskogo nacionalnogo universitetu imeni Tarasa Shevchenka - Bulletin of Kiev Taras Shevchenko National University, 1(34), 47-51 [in Ukrainian].

Shymko, V. (2018a). Object Field of Organizational Culture: Methodological Conceptualization. International Journal of Organizational Analysis, 26(4), 602613. https://doi.org/10.1108/IJOA-03-2017-1135

Shymko, V. (2018b). In Pursuit of the Functional Definition of a Mind: The Inevitability of the Language Ontology. Psiholingvistika - Psycholinguistics, 23(1), 327-346. https://doi.org/10.31470/2309-1797-2018-24-1-403-424

Shymko, V. (2018c). In Pursuit of the Functional Definition of a Mind: the Pivotal Role of a Discourse. Psiholingvistika - Psycholinguistics, 24(1), 403-424. https:// doi.org/10.31470/2309-1797-2018-24-1-403-424

Shymko, V. (2019a). Natural Language Understanding: Methodological Conceptualization. Psiholingvistika - Psycholinguistics, 25(1), 431-443. https:// doi.org/10.31470/2309-1797-2019-25-1-431-443

Shymko, V. (2019b). Zenodoorg. [Online]. [10 October 2019]. Available from: https:// zenodo.org/communities/structural-ontology/

Shymko, V. (2019c). Structural-Ontological Matrix: Proceed to the Identification of Segments. Zenodo. http://doi.org/10.5281/zenodo.2586817

Vasilyuk, F. (1991). The Psychology of Experiencing: The Resolution of Life's Critical Situations. New York: Harvester Wheatsheaf.

Vorobev, V.V. (2008). Lingvokulturologija [Linguaculturology]. Moscow: Rossijskij universitet druzhby narodov [in Russian].

Zamilova, A.V. (2013). Lingvosocionicheskoe modelirovanie russkoj jazykovoj lichnosti: na materiale internet-bloga [Lingvosocionic Modeling of Russian Language Personality: Based on Online Blog. Candidate's Thesis. Kemerovo: Kemerovskij universitet [in Russian].

Шимко Віталій. До питання про місце і роль мови в процесі соціалізації особистості: структурно-онтологічний ескіз

\footnotetext{
АНОТАЦІЯ

Мета. Сформулювати методологічний дискурс щодо місця і ролі мови, які $\epsilon$ пов'язаними з процесом соціалізації особистості і розробити системне уявлення про відповідні функціональні особливості.
} 
On the Question of the Place and Role of Language in the Process...

Методики дослідження. Зазначений дискурс сформульований на основі системного уявлення про соціалізацію особистості, яке, в свою чергу, реалізовано за допомогою структурно-онтологічного методу вивчення предметного поля в міждисциплінарних дослідженнях. Даний метод передбачає побудову спеціальних візуально-графічних матриць, які відображають взаємодію первинного процесу і матеріалу досліджваної системи.

Результати. Робота зі структурно-онтологічною матрицею дозволила проаналізувати функції мови в контексті таких значущих чинників соціалізації, як - комплексна психодинамика, цивілізаційний простір і функція рефрлексії. При цьому рефлексія розглянута на рівні двох планів - первинна (рефлексіязв'язок) і вторинна (ресрлексія-розщеплення). Це дозволило вивести уявлення про роль мови за традиційні рамки роботи з текстом і проаналізувати місце мови в контексті діяльності щодо встановлення зв'язку між індивідами, яка реалізується в специфічній кооперативної ситуачії (Щедровицький). Зокрема, поглянути на мову, як на специфічний інструмент цивілізаційного нормування, механізм якого забезпечується за допомогою рефлексії-зв'язку. Тим самим мову розглянуто крізь призму ії системного впливу на морфологію психіки.

Висновки. Структурно-онтологічний аналіз місця $і$ ролі мови в процесі соціалізації особистості дозволив прийти до побудови гіпотези щодо феномену невдоволення мовою, як тенденції до дистанціювання его-свідомості в процесі індивідуації від мовної онтології. Також було сформульовано аргументацію на користь припущення щодо особливостей впливу невдоволення мовою на культурну діяльність і психодинамічну участь цього феномену в кризі середини життя (Юнг).

Ключові слова: мова, сочіалізачія особистості, індивідуачія, структурна онтологія, системна методологія.

\section{АННОТАЦИЯ}

Цель. Сфрормулировать методологический дискурс в отношении места и роли языка, связанных с процессом социализации личности и разработать системное представление о соответствующих функциональных особенностях. Методики исследования. Указанный дискурс сформулирован на основе системного представления о социализации личности, которое, в свою очередь, реализовано с помощью структурно-онтологического метода изучения предметного поля в междисциплинарных исследованиях. Данный метод предполагает построение специальных визуально-графических матрии, которые отображают взаимодействие первичного процесса и материала исследуемой системы.

Результаты. Работа со структурно-онтологической матрицей позволила проанализировать функции языка в контексте таких значимых фракторов социализации, как - комплексная психодинамика, цивилизационное пространство и функция рефлексии. При этом рефлексия рассмотрена на уровне двух планов - первичная (рефлексия-связь) и вторичная (рефлексиярасщепление). Это позволило вывести представления о роли языка за 
До питання про місие $і$ роль мови в проиесі сойіалізаиї...

традиционные рамки работы с текстом и проанализировать место языка в контексте деятельности по установлению связи между индивидами, которая реализуется в специфической кооперативной ситуации (Щедровицкий). В частности, взглянуть на язык, как на специфический инструмент цивилизационного нормирования, механизм которого обеспечивается посредством рефрлексии-связи. Тем самым язык рассмотрен сквозь призму его системного влияния на морфологию психики.

Выводы. Структурно-онтологический анализ места и роли языка в процессе социализации личности позволил прийти к построению гипотезы о феномене недовольства языком, как тенденции к дистанцированию эго-сознания в процессе индивидуации от языковой онтологии. Также была сформулирована аргументация в пользу предположения в отношении особенностей влияния недовольства языком на культурную деятельность и психодинамическое участие данного феномена в кризисе середины жизни (Юнг).

Ключевые слова: язык, социализация личности, индивидуация, структурная онтология, системная методология. 